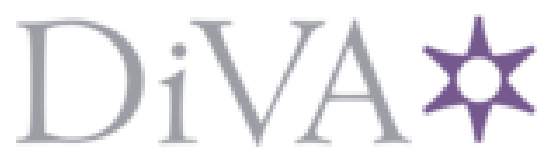

http://www.diva-portal.org

\title{
Postprint
}

This is the accepted version of a paper published in Nordand: nordisk tidsskrift for andrespråksforskning. This paper has been peer-reviewed but does not include the final publisher proof-corrections or journal pagination.

Citation for the original published paper (version of record):

Söderlundh, H., Kahlin, L., Weidner, M. (2020)

Arbetsmigration och flerspråkig interaktion på byggarbetsplatser

Nordand: nordisk tidsskrift for andrespråksforskning, 4(2): 93-110

https://doi.org/10.18261/issn.2535-3381-2020-02-04

Access to the published version may require subscription.

N.B. When citing this work, cite the original published paper.

Permanent link to this version:

http://urn.kb.se/resolve?urn=urn:nbn:se:sh:diva-43098 


\section{Arbetsmigration och flerspråkig interaktion på byggarbetsplatser}

\section{Hedda Söderlundh, Linda Kahlin och Matylda Weidneri}

\section{Inledning}

Den här artikeln handlar om den flerspråkighet som finns på svenska byggarbetsplatser och som är resultat av arbetskraftspendling inom EU. I artikeln studeras kedjor av arbetsdirektiv mellan personer som har olika funktioner och som huvudsakligen talar olika språk på arbetet. Svenska, polska, ukrainska och engelska är de språk som framför allt berörs. Syftet med artikeln är att belysa hur hantverkarna organiserar arbetet i relation till de språk som finns på arbetsplatsen och som faktiskt används under yrkesvardagen. Två forskningsfrågor är utgångspunkt: För det första frågar vi hur hantverkarna hanterar mångfalden språk under pågående arbete genom att titta på kedjor av arbetsdirektiv. För det andra frågar vi, med inspiration från Sarangi och Roberts (1999, se vidare avsnitt 3), hur den interaktionella ordning som framträder i kedjorna samverkar med en rutinartad institutionell ordning för språkval, vilken har generell bäring för hur arbetsplatserna hanterar mångfalden språk. I relation till tidigare undersökningar av flerspråkigt arbetsliv (se t.ex. Angouri 2014; Mondada 2007) bidrar artikeln med insikter om praktiker och språkval i den manuella sektor där arbetspendlande EU-medborgare utför en betydande del av arbetet (jfr även Kraft 2017; 2020).

Att studera yrkesinteraktion på arbetsplatser med inrest arbetskraft ger kunskap om flerspråkiga praktiker och flerspråkigt arbetsliv på den europeiska arenan i relation till hur det är att tillfälligt arbeta i annat EU-land, men också i relation till språk som resurser för såväl individer som verksamheter. Teoretiskt kan arbetskraftspendlingen relateras till globaliseringens sociolingvistik (Blommaert, 2010; Coupland, 2003), som uppmärksammar sociolingvistiska effekter av samtidens globalisering och mobilitet av såväl människor som språkliga resurser. Globaliseringen ger upphov till nya möjligheter för människor att t.ex. söka arbete i andra länder, men den medför också nya sociala och språkliga effekter som uppstår då människor ska kommunicera på nya marknader. Effekterna gäller både de som flyttar och de som redan befinner sig på platsen för immigrationen, eftersom de samlade språkliga resurserna nu ska användas i samma lokala kontext. Byggarbetsplatserna i artikeln 
är ett exempel på detta i och med att svenska och utländska hantverkare möts för att arbeta tillsammans.

\section{Forskningsbakgrund}

Flerspråkigt arbetsliv har hittills framför allt studerats på multinationella företag och då med fokus på engelska som lingua franca bland tjänstemän, så kallade "white-collar workers" (se t.ex. Gunnarsson, 2014; Lønsmann, 2015; Räisänen, 2013). Ett återkommande resultat är att språkval är en resurs för att organisera deltagandet, men också för att särskilja aktiviteter från varandra. Som exempel kan nämnas Mondadas (2007) välkända studie av en operation där läkaren växelvis talar franska med det assisterande teamet, växelvis engelska till en extern publik via videolänk. Språkväxlingarna är en anpassning efter gruppens olika språkliga preferenser, samtidigt som de skiljer den instruktion som rör videosändningen från kommentarer som rör operationen. Den manuella yrkessektorn ("blue-collar workers"), i sin tur, har inte studerats i samma omfattning (Angouri, 2014), även om flera studier genomförts under de senaste åren. Bland dessa kan nämnas Handford och Matous (2011; 2015), Kraft (2017; 2020), Gluch och Räisänen (2009) samt Theodoropoulou (2019), som alla undersöker flerspråkighet i byggsektorn, samt Goldstein (1997), Nikolaidou (2014) och Hovens (2019), som studerar flerspråkighet bland arbetare på verkstadsgolv. På större byggarbetsplatser är det inte ovanligt att det saknas kunskaper i ett gemensamt lingua franca (jfr Kraft, 2017) och de språkpolicyer som blivit allt vanligare i tjänstemannasektorn saknas helt. På flerspråkiga byggarbetsplatser i Qatar rapporterar Theodoropoulou (2019) om en mångspråkig norm, även om engelska är det överordnade språk som används för att organisera arbetet. För att maximera effektiviteten används ord och uttryck från en rad olika språk i det faktiska arbetet.

De studier som liksom denna uppmärksammar arbetspendlare visar att yrkeslivet präglas av flerspråkighet och tillfälliga arbetskonstellationer med team från olika språkområden (se t.ex. Kraft 2017; Theodoropoulou 2019). Undersökningarna av Kraft (2017) och Handford och Matous (2015) visar betydelsen av en "language broker" som möjliggör kommunikation mellan olika (kulturella) grupper. Positionen går ut på att förmedla information och samordna det manuella arbetet $\mathrm{i}$ ett arbetslag, men personen kan också efterfrågas utanför arbetstid för t.ex. tolkning vid sjukhusbesök. Även på de arbetsplatser vi har studerat finns individer som fungerar som language brokers och vi återkommer nedan till den förstnämnda funktionen, alltså förmedling av information över flera språk under pågående arbete. Genom analysen av 
just kedjor av arbetsdirektiv kan vi ge fördjupad kunskap om det språkliga arbete som dessa individer gör.

Studier som fokuserar den yrkesrelaterade interaktionen på byggarbetsplatser i allmänhet visar en hierarkiskt präglad arbetsmiljö där enskilda samtal påverkas av att miljöerna är bullriga. Det finns inte särskilt stort utrymme för relationellt samtalande och man talar framför allt med varandra ifall det uppstår problem och när maskinerna tystnat (Handford \& Matous, 2015). Under pågående byggarbete är deiktiska uttryck vanliga (se t.ex. nedan i Ex. 3: har ru sett vattne där) och gester används i stor utsträckning (Handford \& Matous, 2011. Se även Lilja \& Tapaninen, 2019 för multimodal analys av interaktion på en yrkesskola inom byggsektorn). På den flerspråkiga byggarbetsplatsen är det vanligt att ord för verktyg och material används på samhällets omkringliggande majoritetsspråk och då som inskott i andra språk (jfr Franziskus \& Gilles, 2012). Studier från andra manuella yrken där deltagarnas lingvistiska repertoarer inte överlappar visar att interaktion kan hållas till ett absolut minimum. T.ex. konstaterar Lønsmann och Kraft (2018) i en studie av leveransmottagande vid stora varuhus att all nödvändig information ligger i det ordernummer som följer med leveransen, och arbetet kan därför skötas utan gemensamma språkkunskaper. Vidare uppmärksammar Strömmer (2016) i en undersökning av städbranschen att manuellt arbete ofta sker i ensamhet och under tystnad, vilket ger få möjligheter till språkinlärning för de många migranter som finns i yrket. Resultatet återkommer hos Piller och Lising (2014) i studien av filippinska arbetare i Australiens köttindustri: När språkkunskaper inte är ett krav för anställning ger inte heller arbetet några vidare möjligheter för språkinlärning. Genom att vi följer arbetsmigranter är vårt fokus dock ett annat än de undersökningar som gjorts av andraspråkstalare (för svenskt yrkesliv se t.ex. Jansson, 2013; Kahlin \& Tykesson, 2019; Nelson, 2014): individerna vi följer är i landet en viss period och lär sig inte nödvändigtvis svenska.

\section{Material och analysmetod}

Materialet har samlats in för ett forskningsprojekt om arbetskraftspendling och flerspråkiga byggarbetsplatser i Sverige som finansierats av Östersjöstiftelsen. ${ }^{\text {ii }}$ För artikeln har vi valt ut två byggarbetsplatser som skiljer sig från varandra framför allt ifråga om storlek, temporalitet och spatialitet. På arbetsplatserna finns inget lingua franca som är gemensamt för alla arbetare. 


\subsection{De två arbetsplatserna: Grävarbete och husbygge}

Den första arbetsplatsen representerar en liten arbetsplats. Sex personer arbetar med att reparera och byta ut ett nedgrävt avloppsrör och en trasig pump. Arbetet är avgränsat i tid och rum till en uppgrävd grop. Den ansvariga firman är svensk och arbetsledaren samt en grävmaskinist är svenska. Övriga fyra utförare är hemmahörande i Polen och arbetar periodvis i Sverige. Lagbasen för det polska teamet har arbetspendlat till Sverige under tolv år och han har tidigare arbetat med den svenska arbetsledaren. Grävarbetet kräver stor yrkesskicklighet: marken är porös och gropen djup, vilket medför säkerhetsrisker.

Två forskare (Kahlin och Weidner) har filmat arbetet i gropen med handburna aktivitetskameror under två halva arbetsdagar. Inspelningarna är gjorda från markplanet där grävmaskiner och ansvarig arbetsledare befinner sig. Nere i gropen arbetar de polska utförarna och deras lagbas, här kallad Wacek. Vi fick kontaktuppgifter till lagbasen efter telefonsamtal med firmans ägare, och samtliga deltagare gav sitt informerade samtycke till att delta i inspelningarna på plats vid gropen. Under projektet har vi också följt lagbasen på en annan byggplats, där han arbetade som snickare för samma firma, samt genomfört en intervju med honom på polska (Weidner). Vi har också visat några av filmerna för honom och ställt följdfrågor om arbetet.

Det andra bygget representerar en stor arbetsplats där en byggentreprenör uppför ett nytt område med flerbostadshus. Byggområdet är stort som ett kvarter och varje våningsplan och lägenhet utgör en egen rumslighet. Över hundra personer har varit inloggade på byggarbetsplatsen när vi genomför våra observationer. Vi får tillträde genom en svenskestnisk underentreprenör som arbetar med köksmontering och golvläggning. De har bl.a. ett team med åtta ukrainska hantverkare på plats och i analysen står arbetsledningens samtal med dessa i fokus. I det läge vi följer dem arbetar de framför allt med att åtgärda mindre problem i de nästan färdiga lägenheterna. Den ukrainska lagbasen, här kallad Vanko, är relativt ny och det är oklart om han tidigare arbetat inom byggbranschen. Oklarheten beror på att det var svårt att ställa frågor under pågående byggarbete, och deltagarna hade inte tid för intervjuer. Tre forskare genomförde observationer under totalt en veckas tid på den stora byggarbetsplatsen (Kahlin och Söderlundh, samt Leelo Keevallik som ingår i den större forskargruppen). Det inspelade materialet uppgår till ca 10 timmar, varav drygt 1 timme rör det ukrainska teamet. Vi har därtill intervjuat den svenskspråkiga platsledningen (Söderlundh). Informerat samtycke gavs efterhand som nya situationer uppstod och deltagare 
kom och gick. För de ukrainska deltagarna skedde det på ukrainska via lagbasen, då ingen av oss forskare behärskar ukrainska eller ryska. I analysarbetet har vi fått hjälp med översättning av fil.dr Natalia Ringblom.

De utländska hantverkare som deltar i studien är antingen utstationerade i Sverige från ett utländskt företag eller verksamma i landet via EU:s uppehållsrätt som egenföretagare eller anställda av ett svenskt företag. Statistik visar att $17 \%$ av den totala arbetskraften inom branschen byggverksamhet i Sverige består av utstationerad arbetskraft och de flesta av dem är anställda av ett polskt företag (Arbetsmiljöverket, 2019). Statistik saknas över hur många EU-medborgare som är verksamma som egenföretagare eller anställda av ett svenskt byggföretag, eftersom dessa saknar krav på registrering.

\subsection{Utgångspunkter för analysen}

Forskningen är induktiv på så vis att frågorna för artikeln uppkommit under bearbetningen av materialet. Vi har sökt igenom observationsanteckningar och videoinspelningar efter situationer då olika språk förekommer, men också noterat vad hantverkarna arbetar med för uppgift.

Den första frågeställningen, som rör hur språken hanteras och organiseras interaktionellt under arbetet, besvaras genom analyser av samtal och samtalssekvenser där deltagare med olika befattningar talar med varandra för att lösa en och samma arbetsuppgift. Det typiska mönstret är att arbetsledningen identifierar ett problem (under ett samtal på svenska) som behöver åtgärdas, vilket följs av ett direktiv till lagbasen på engelska, som i sin tur för information eller direktiv vidare till utförarna på polska eller ukrainska, alternativt utför arbetet själv. Därmed uppstår kedjor av informationsöverföring som involverar flera språk. Att det är just en kedja ser vi genom att ämnet (arbetsuppgiften) återkommer i alla led och deltagarna kan använda samma ord eller gester som transportabla resurser i de olika stegen av överföring. Utgångspunkten för analysen är samtalsanalytisk (se t.ex. Sidnell, 2010 respektive t.ex. Mondada, 2004 för exempel på flerspråkiga samtal). Vi använder oss av Mondadas transkriptionssystem (https://www.lorenzamondada.net/multimodal-transcription) för att fånga hur språkval och språkliga strukturer utvecklas i kedjorna. Det innebär att vi lägger särskild vikt vid multimodalitet, inklusive t.ex. de gester, blickriktningar etc. som behandlas som betydelsebärande av deltagarna. Vad vi vet har kedjor av detta slag inte studerats tidigare (jfr dock Strömmer, 2016 som uppmärksammar en liknande kedja i interaktionen mellan 
uppdragsgivare, företagsledning och utförare i städbranschen). Redan under observationerna framstod dock kedjorna som särskilt intressanta i relation till just flerspråkighet eftersom de utgör en av få aktiviteter där deltagare med olika befattningar och språk talar med varandra. Kedjorna binder ihop arbetsplatsernas organisation och visar hur flerspråkigheten hanteras så väl i enskilda interaktioner som på ett mer övergripande plan.

Genom analysen av kedjor undersöker vi interaktionsordningen (Sarangi \& Roberts, 1999), vilket här står för samtalsmönster och rutiner i samtal under arbete som involverar hantverkare från olika länder. Begreppet interaktionsordning kommer ursprungligen från Goffman (1974) men har vidareutvecklats för framför allt institutionella samtal av Sarangi och Roberts (1999). Flerspråkigheten produceras och hanteras i enskilda interaktionen och behöver förstås i relation till den specifika situationen och till deltagarnas reaktioner och svar (Hazel \& Svennevig, 2018). Som exempel kan nämnas Auers (1984) begrepp diskursrelaterad och deltagarrelaterad kodväxling, som har betydelse för vår analys av särskilt gropen. Den diskursrelaterade växlingen hanterar inramning av vad som sägs medan den deltagarrelaterade pekar ut deltagandet i interaktionen, och relevantgör identiteter och gruppmedlemskap. De två är dock inte ömsesidigt uteslutande, snarare är växlingarna ofta flerfunktionella.

Den andra frågeställningen, som handlar om hur den interaktionella ordningen samverkar med en rutinartad institutionell ordning för språkval, besvaras genom att vi lyfter blicken från enskilda exempel och diskuterar generella mönster för språkval på de två arbetsplatserna. Liksom Sarangi och Roberts (1999) betraktar vi denna institutionella ordning som skapad och återskapad i enskilda samtal, i form av normer, regler och rutiner som deltagarna kontinuerligt förhåller sig till. Sarangi och Roberts användning av institutionell ordning, bygger på Berger och Luckmanns (1991) begrepp och innefattar en gemensam kunskapsbas som legitimerar och upprätthåller rutiner och förhållningsätt. Den bygger på en ömsesidig relation med rutinmässiga professionella samtal. För att se ett återkommande mönster har vi kompletterat näranalysen av interaktion med etnografisk kunskap om kontext och organisation utifrån den medföljande observationen på byggarbetsplatserna.

\section{Analys och resultat}

Nedan besvaras först (4.1) den första frågeställningen genom analys av tillfällen när hantverkare med olika befattningar ingår i en samtalskedja för att lösa en arbetsuppgift. I 
materialet kan detta utspelas under en sekvens i ett samtal, ifall alla befinner sig på samma plats. Det är typiskt för arbetet på den mindre arbetsplatsen i gropen. Kedjan kan också vara utsträckt i tid och rum, vilket är vanligast på den större arbetsplatsen. Därefter (4.2) besvaras den andra frågeställningen rörande en institutionell ordning för språkval.

\subsection{Korta kedjor och snabba språkbyten på den mindre arbetsplatsen}

Vid den mindre arbetsplatsen, gropen, utförs allt arbete inom ett begränsat område som är synligt för alla deltagare. Den som inte deltar i arbetet för tillfället står vanligtvis vid gropen och följer arbetet med blicken, redo att utföra en uppgift.

Vi kan vid flera tillfällen se hur mycket enkla direktiv går i en kedja från arbetsledare (Berra) till lagbas (Wacek) och därefter (vanligen) vidare till övriga polska utförare. Detta visar sig t.ex. vid ett tillfälle när Wacek befinner sig nere i gropen och Berra står ovanför, jämte två polska utförare. Kedjan börjar med att Berra säger till Wacek att be sina killar att hämta en bra pump (tell the guys to bring the good pump). Wacek vänder sig omedelbart mot det polska arbetslaget och ger en instruktion om var de ska hämta pumpen: tam w środku jeszcze jak te białe drzwi otworzysz, to- (där i mitten, när du öppnar den vita dörren, då-). I Waceks instruktion nämns aldrig pumpen. Snarare än att översätta ger han information om var de ska hämta den pump som behövs, och han förutsätter därmed att de redan uppmärksammat att en pump behövs, antingen genom att de förstått Berras direktiv eller gjort en professionell bedömning av situationen.

Mönstret är representativt för kedjorna av arbetsdirektiv vid gropen. I regel börjar de med korta direktiv från Berra till Wacek på engelska. I nästa steg för Wacek informationen vidare (som i Ex. 1 och 2 nedan) på polska, eller genomför arbetet själv.

Exempel 1. ${ }^{i i i}$ Wacek (W/*), polsk lagbas och Kamil (K/@), polsk utförare gräver runt rören $i$ gropen. Berra $(B /+)$, svensk arbetsledare, står ovanför.

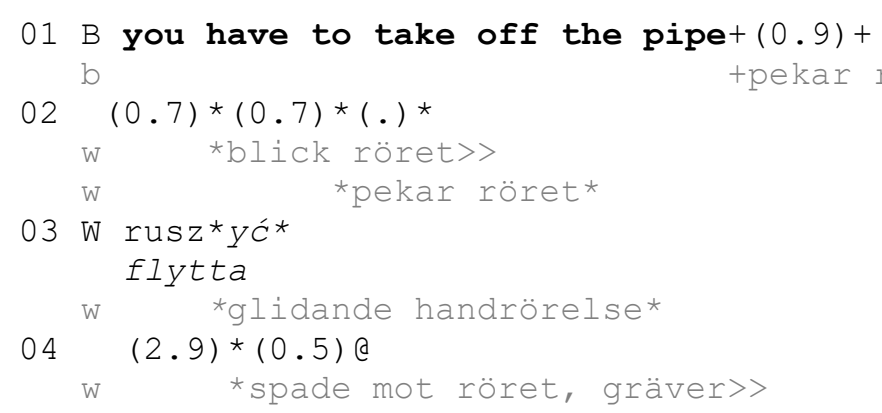


Exempel 2. Wacek (W/*), polsk lagbas, och polsk utförare (PU) är i gropen. Berra $(B /+)$, svensk arbetsledare, står lutad över ett cementrör på en avsats i gropen. Pawel $(P / \delta)$, polsk utförare, står ovanför.

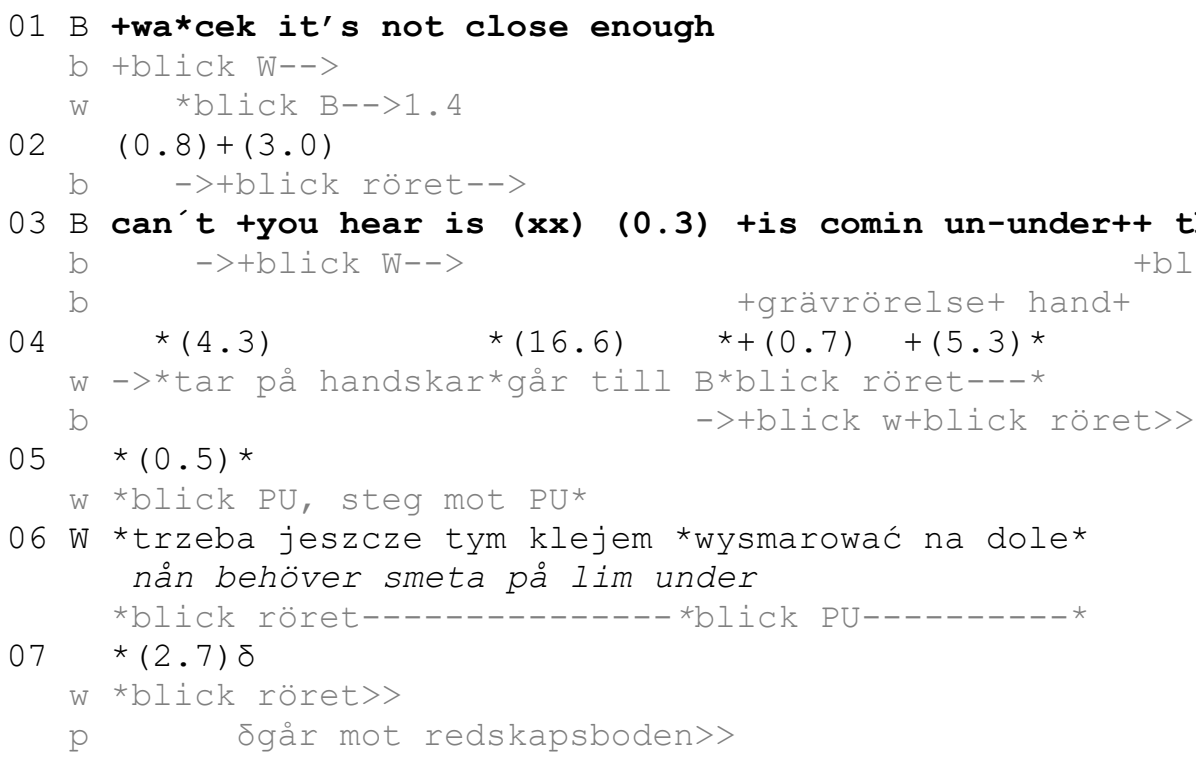

De fetmarkerade arbetsdirektiven i Exempel 1-2 från Berra koordinerar eller korrigerar ett pågående manuellt moment. Direktiven är kortfattade och deiktiskt präglade (t.ex. yttrandet it's not close enough), vilket kan förklaras med att arbetsmomentet är pågående och synligt för deltagarna. De är tydligt riktade mot Wacek genom blickriktningen och användandet av hans förnamn (se Ex. 2), och de besvaras sällan verbalt av Wacek. Istället utgörs responsen av att han omformulerar, anpassar och för instruktionen vidare till någon i sitt team.

Kedjorna med direktiv befäster Berras position som arbetsledare och organisatör av arbetet på en övergripande nivå. Wacek, i sin tur, fungerar samordnande för hela den polska gruppens arbete, och utgör en länk i hierarkin mellan Berra och utförarna. Wacek fungerar därmed tydligt som en language broker (jfr Kraft, 2017) under det pågående manuella arbetet. Som visas i Exempel 2 är detta inte nödvändigtvis en fråga om att översätta information mellan hierarkins olika lager, utan Wacek har mandat att omformulera arbetet och ge ytterligare direktiv på en mer konkret nivå (nån måste smeta på lim). Sammantaget har vi härmed dokumenterat ett återkommande mönster bestående av korta arbetsdirektiv på engelska riktade till lagbasen, som förmedlar vidare på polska till utförarna eller utför arbetet. 
Nästa transkription (Ex. 3) visar en sekvens som inkluderar alla befattningar och språk i gropen. Den innehåller dels ett slags informationskedja, dels ett direktiv som följer kedjemönstret ovan. När sekvensen inleds befinner sig en av grävmaskinisterna, Gunnar, ovanför gropen. På motsatt sida står Berra och blickar ned mot arbetet. Längst ned i gropen arbetar Kamil, böjd över rören. Något högre upp på en avsats står Wacek. I exemplet uppfattar grävmaskinisten ett problem med ett rör som läcker vatten.

Exempel 3. Berra (B/+), svensk arbetsledare, och Pawel (P/Ф), polsk utförare, står ovanför gropen. Wacek $(W / *)$, polsk lagbas, står på en avsats halvvägs ned i gropen. Kamil (K/@), polsk arbetare, gräver i gropen. Gunnar $(G / \beta)$, svensk grävmaskinst, är i grävmaskinen på markplan.

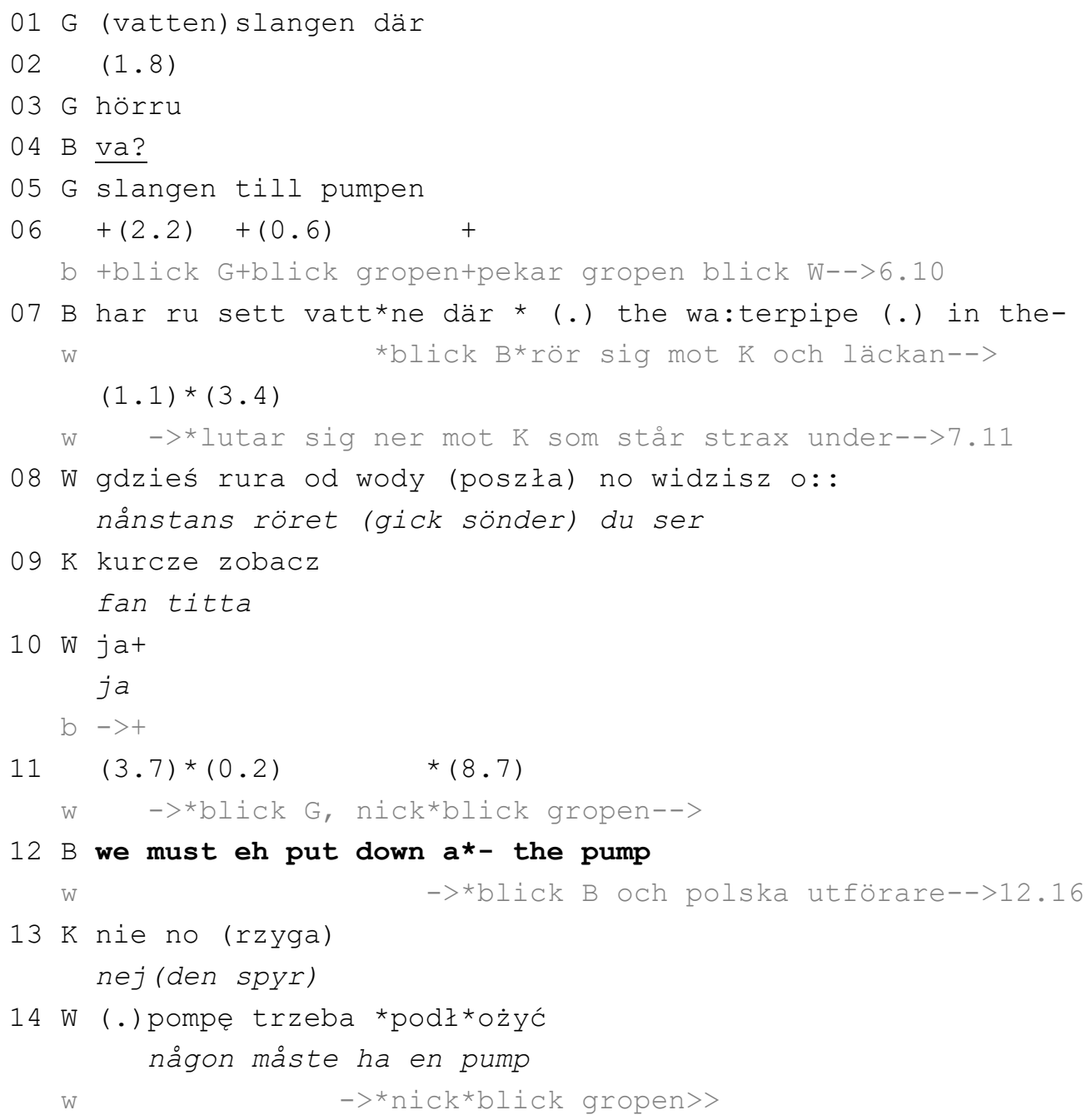

Det är ovanligt att grävmaskinisten Gunnar interagerar med övriga deltagare men från sin position har han god överblick. Han pekar på läckan och uppmärksammar de andra verbalt på svenska, samtidigt som han tittar på Berra. Att han talar svenska till Berra, och därmed inte självklart inkluderar de övriga närvarande, visar på sambandet mellan deltagare, språkval och 
arbetsbefattning som finns i gropen: Användningen av svenska förstärker Berras funktion som koordinerande arbetsledare mellan språkgrupper och hantverkare. Efter en kort reparationssekvens ( $\operatorname{rad} 3-4)$, pekar också Berra mot läckan samtidigt som han orienterar sig med blicken mot Wacek och inleder sitt yttrande med att säga hans namn (jfr även Ex. 2 ovan). Trots att yttrandet är riktat mot Wacek inleds det på svenska, men Berra växlar till engelska innan han avslutar ( $\operatorname{rad} 7$ ). Wacek i sin tur avbryter Berra och överför informationen på polska till Kamil nere i gropen. Kamil bekräftar och vänder blicken mot vattenläckan. Noteras kan att den del som läcker vid ett första tillfälle kallas för slang och sedan för rör. Detta verkar dock inte leda till någon förvirring bland deltagarna, som alla orienterar sig med blick och kropp mot vattenläckan. På rad 9 och 10 ser vi också en utvärderande sekvens på polska där utförarna sinsemellan kommenterar problemet. De visar engagemang i det gemensamma projektet och utvärderar situationen. Först i denna sekvens pekas läckan också explicit ut som ett problem genom det värderande yttrandet kurcze zobacz (fan titta, rad 9). Denna sekvens är ett av de sällsynta tillfällen när relationellt tal förekommer på polska i materialet under arbetet. Sammantaget har vi så långt en kedja av informationsdelning fram till rad 12. Informationen om det läckande vattnet har under kort tid delats till samtliga närvarande deltagare på tre olika språk. I kedjan ges ingen verbal återkoppling till den person som förmedlar informationen utan personen som är mottagare orienterar sig direkt mot nästa person och för informationen vidare på ett nytt språk. Dock avslutar Wacek informationskedjan med en nick mot grävmaskinisten Gunnar, som först identifierat problemet (rad 11), då läckan noterats av Kamil nere i gropen och alla aktiva deltagare är uppmärksammade på problemet.

På rad 12 ger Berra ett direktiv på engelska som pekar ut hur problemet kan åtgärdas: we must put down a- the pump. En andra kedja i arbetshierarkin inleds, i och med att Wacek överför direktivet på polska (rad 14), och en utförare som står ovanför gropen hämtar en pump. Direktivet och språkvalet följer gängse mönster på arbetsplatsen, och läckan behandlas av Berra i denna fas av samtalet på ett rutinartat sätt. Kommunikationen är trots den hierarkiskt ordnade gången av information påfallande tidseffektiv och kedjan genomförs, trots inskott av relationellt tal, inom 60 sek.

\subsection{Långa kedjor och språkval i tid och rum på det stora bygget}

På det stora bygget är kedjorna utspridda över tid och rum. I det inspelade materialet finns endast en kedja i sin helhet och det är den som valts ut för analys nedan. Den rör håltagning 
mellan våningsplan och börjar under ett möte mellan projektledning och underentreprenörens projektledare (steg 1), vidare mellan projektledare och lagbas för det ukrainska teamet på byggområdet (steg 2), och slutar mellan lagbas och ukrainska hantverkare i ett förrådsrum på byggområdet (steg 3). Vi ser ingen återkoppling uppåt i kedjan, men en sådan kan ha förekommit när vi inte var på plats.

Steg 1. Möte i byggboden. Kedjan börjar under ett underleverantörsmöte (UE-möte), dvs. ett inplanerat möte mellan entreprenörens platsledning och underentreprenörernas projektledare. På mötet deltar fyra personer: platschefen och en arbetsledare från den svenska entreprenören samt två projektledare från den svensk/estniska underentreprenören (den ena inrest från Estland över dagen). Mötesspråket är engelska, men därtill förekommer estniska i telefonsamtal och de övriga deltagarna pratar svenska med varandra i sidosekvenser. Före mötet växlar platschefen från svenska till ryska när han riktar sig till lagbasen för det ukrainska teamet, Vanko, som tillfälligt är i rummet. Detta visar att man har god kännedom om de närmaste kollegornas språkliga repertoarer. Språket kommenteras av en av deltagarna och kunskapen pekas i och med detta ut som ovanlig: "nu ska ni få höra platschefen här va: da, niet, davai (skratt)" [videoinspelning 18/12]. Kommentaren är antagligen (främst) riktad till den svenskspråkiga forskaren på plats.

De hål som man talar om ska rymma vattenledningar mellan våningsplanen i huskropparna. Arbetet har påbörjats av en annan underentreprenör, men med otillfredsställande resultat. På UE-mötet initieras ämnet av den estniske kollegan med orden "this parquet shit" och tillägget "It seems they have drilled from down to up because splinters is everywhere." Platschefen håller med och påpekar att nya hål måste göras. De första har av misstag dessutom fyllts med flytspackel. Under mötet får underentreprenören i uppdrag att borra en gång till, underifrån, genom spacklet. Den estniske kollegan föreslår att man ska ta upp ett "five millimeters hole in the middle (pekar uppåt) and then drill (cirkulerande rörelse med handen)". Förslaget bekräftas av platschefen med tillägget "yeah, no problem with a 30 millimeters [drill] (måttar med fingrarna)". I diskussionen visar deltagarna yrkeskunskap på en plats som är tidsligt och rumsligt avskilt från det manuella arbetet.

Steg 2. Instruktion förs vidare till lagbasen. Efter mötet går underentreprenörens ena projektledare, här kallad Peter, ut på bygget och träffar den ukrainske lagbasen Vanko utanför en hiss. På platsen finns också två svenska hantverkare, och Peter talar svenska när han svarar 
på frågor om hålen i parketten, men engelska när han berättar för Vanko att han har med sig en ny lista med arbetsuppgifter från UE-mötet. Växlingarna är deltagarrelaterade på så sätt att språkvalet indikerar mottagare för yttrandet (jfr Hazel \& Svennevig, 2018). Vid en punkt inne i hissen initierar Peter en reparation av det gemensamma mediet svenska, genom en kort uppåtnick som riktas mot Vanko. Nickningen har den effekten att hantverkaren repeterar frågan på engelska (se Ex. 4, rad 3). Vanko går i och med språkbytet från ett slags överhörare (jfr Goffman, 1981) på ett språk han enligt egen uppgift inte talar själv, till att vara direkt tilltalad på engelska. Kanske sker det i hissen för att man nu befinner sig på en tydligt avgränsad yta, och växlingen kan ha delvis rumslig förklaring. Vanko bekräftar språkvalet i nästa tur och agerar som direkt tilltalad genom att svara på hantverkarens fråga när den omformuleras på engelska. Växlingen har betydelse för arbetet eftersom det är Vankos team som ska lösa uppgiften och den är på så vis flerfunktionell.

Exempel 4. I hissen. Svensk hantverkare (H), Peter (P/*), svensk projektledare för UE, Vanko (V), lagbas ukrainska hantverkare inom UE.

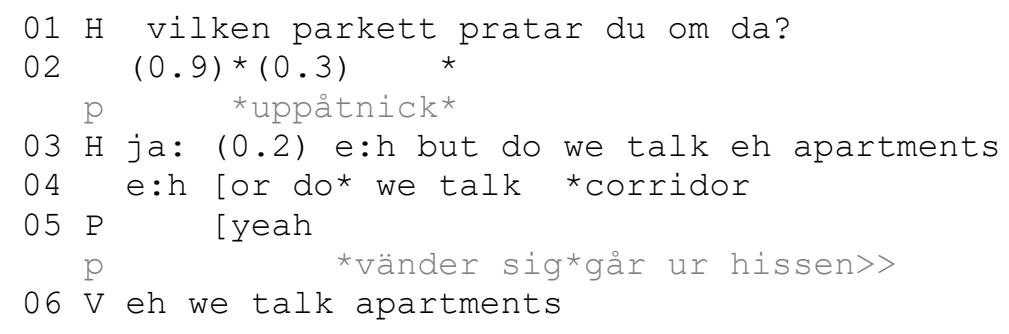

I källaren fortsätter en av de svenska hantverkarna att tala med Vanko om hålen i parketten. Peter inleder samtidigt ett samtal med den andre hantverkaren om en brandfog. Vid en punkt vänder sig Peter helt om mot Vanko och begär också strax verbalt att få ingå i samtalet mellan Vanko och hantverkaren genom att fråga what, med blicken mot Vanko. Transkriptionen (Ex. 5) nedan återger det efterföljande samtalet mellan Vanko och Peter, som alltså utgör steg 2 i kedjan.

Exempel 5. Peter (P/*), svensk projektledare UE, Vanko(V/@), lagbas ukrainska hantverkare inom UE.

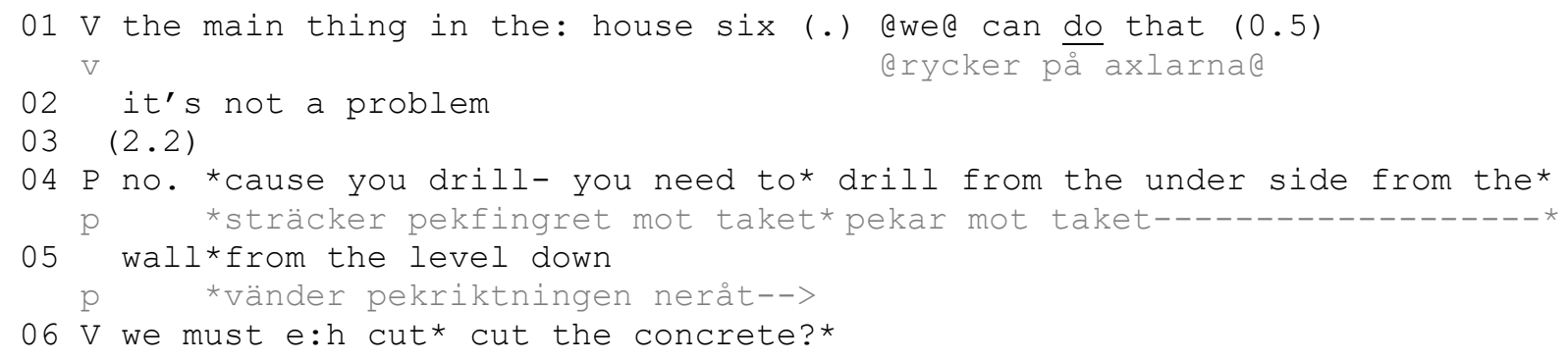




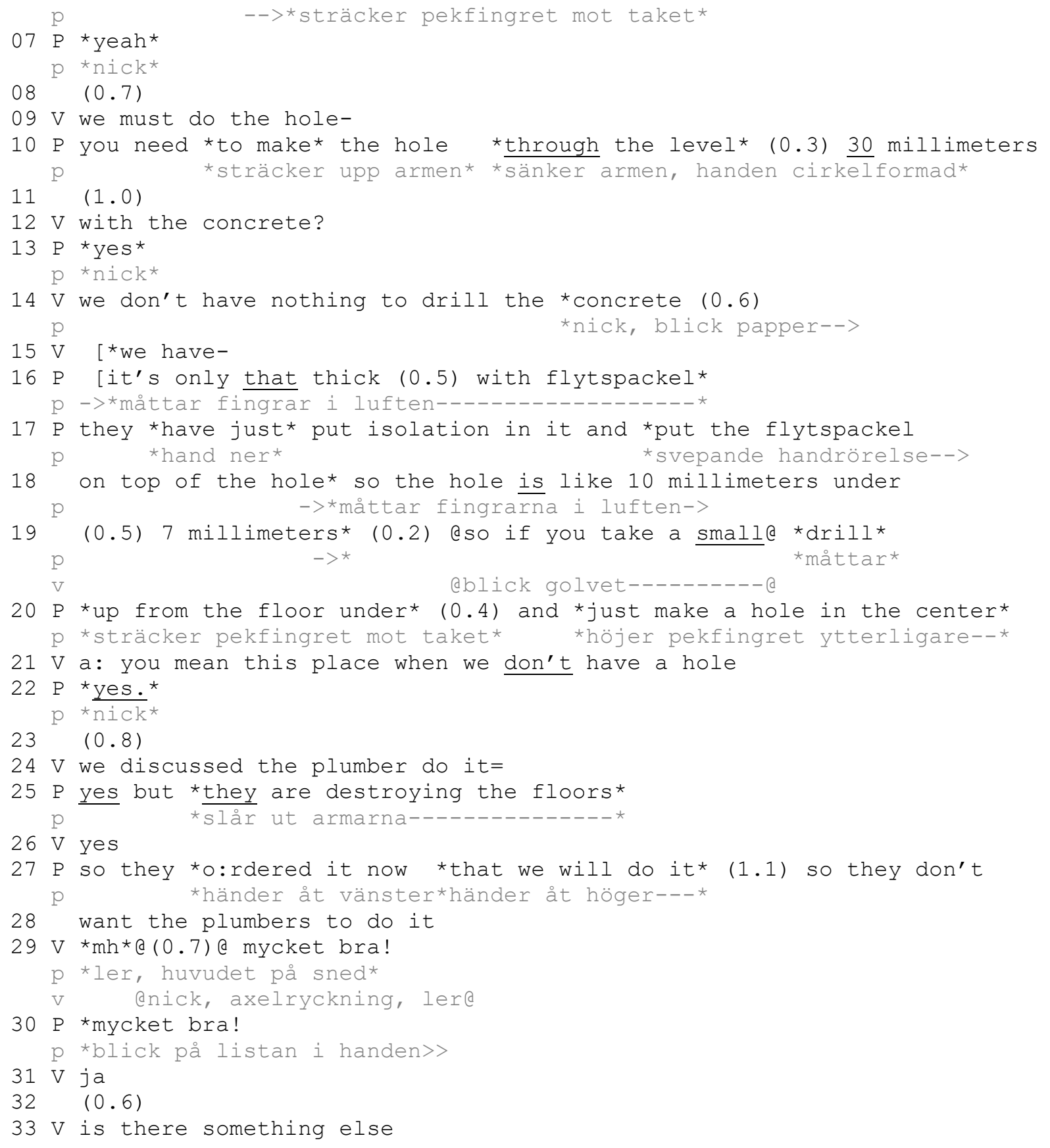

Vanko svarar genom ett erbjudande och bekräftande om att hans team kan göra arbetet, det är inga problem ( $\operatorname{rad} 1-2)$, men det avslås av Peter med det disprefererade svaret no, vilket stannar upp samtalet (jfr halting device, Stivers, 2004) och ger Peter talutrymme att ge sin instruktion om hur borrningen ska gå till, nämligen från undersidan. Riktningen för borrningen är liksom under UE-mötet i fokus och Peter återkommer till den inte mindre än tre gånger: from the under side, from the level down, from the floor under. Därtill repeteras den storlek på borren som nämndes på mötet (30 millimeter), samt informationen om att först borra i hålens centrum. Gesterna visar borrningens riktning ( $\operatorname{rad} 4-11,21-22)$ och det är en 
viktig del av instruktionen, som fungerar som en transportabel resurs mellan steg 1 och steg 2 i kedjan.

Peter visar i just detta exempel en stark mottagaranpassning till Vankos bakgrund som lingua franca-talare av engelska genom ett långsamt samtalstempo och ett övertydligt betonande av t.ex. relativt informationslätta ord som through samt genom att förklara på tre olika sätt att borrningen måste ske underifrån. Instruktionen är onekligen utmanande, eftersom de inte befinner sig på den plats där uppgiften ska utföras och därför måste beskriva riktning och föremål verbalt. Vanko ber också om förtydliganden tre gånger rörande vad som ska borras (rad 6, 9 och 12), och frågar efter bekräftelse på att han förstått vilka hål man talar om (so you mean this place when we don't have a hole). Vikten av att instruktionen uppfattas rätt understryks senare av Peter i ett intervjuliknande samtal. Han berättar då att han aldrig ger liknande arbetsinstruktioner över telefon för att han "vill se i deras ögon att de förstår". Att tala öga mot öga ger också utrymme att använda multimodala resurser, vilket vi kan se i exemplet med håltagning ovan.

I Exempel 5 förekommer svenska ord för byggtermen flytspackel och i andra samtal förekommer t.ex. det specifika begreppet $U E$-möte, som alltså står för möte mellan arbetsledare och underentreprenör. Precis som i tidigare studier förekommer dessa termer generellt som omarkerade inslag av svenska i engelskan, och de behandlas som en förväntad och accepterad del av interaktionen, utan pauser eller metakommentarer (jfr Svennevig, 2018). Vanko avslutar också sekvensen med det svenska uttrycket mycket bra!, vilket Peter upprepar. Det sistnämnda tolkas här som crossing (Rampton, 1998) och en identitetshandling från Vankos sida. Genom inslaget av svenska visar Vanko tillhörighet med den svenska byggoch samhällskontexten, och det kan tolkas som en kommentar till att hans team just fått i uppdrag att genomföra en borrning som ett annat team misslyckats med (jfr rad $27 \mathrm{ff}$ ). Peters spegling av mycket bra! i den efterkommande turen fungerar som ett slags bekräftande också av detta.

Steg 3. Lagbasen instruerar det ukrainska teamet. Efter mötet går Vanko till ett förråd för bl.a. skruv och verktyg, där flera ur det ukrainska teamet befinner sig. Vanko berättar i stort sett omgående att de har en ny uppgift att utföra. ${ }^{\text {iv }}$ Den presenteras - på ryska - som ett “problem” som uppstått (Там, короче, знаешь какая фигня?) och efter en fråga om varför det inte finns hål svarar Vanko på ukrainska att problemet uppstått då man gjutit flytspackel 
(бо коли вони заливали flytspackel). Som framgår används det svenska ordet flytspackel som ett inskott i ukrainskan också mellan de ukrainska hantverkarna, och flytspackel är därmed ett svenskt fackord som återkommer i kedjans olika led. Likaså återkommer storleken för hålen: тридцадка має бути дирка (hålen ska vara 30). I samtalet är Vanko fokuserad på det som gruppen behöver göra först, nämligen inspektera vilka lägenheter som har hål och vilka som inte har det. Han beskriver också att det kan finnas flera hål, men att bara några behöver åtgärdas. Som lagbas preciserar han därmed arbetet, istället för att enbart föra vidare en instruktion. Vi kan också märka ett visst avståndstagande till uppgiften: Hantverkaren han talar med frågar vad de behöver och svaret blir att de behöver en bra borr, men jag vet inte hur länge den kommer att hålla (сверло добре, але не знаю чи хватить його надовго). Samma avståndstagande återfanns i samtalet med Peter (we don't have nothing to drill the concrete), vilket Peter behandlade som en irrelevant invändning genom att svara att betongen ifråga är tunn. Direkt efter samtalet påbörjar Vanko och två andra ukrainska hantverkare att inspektera lägenheterna för att se var de behöver ta upp nya hål.

Sammantaget ser vi ovan hur instruktionen om håltagningen förs vidare i bygghierarkins led. Kedjan början på ett UE-möte, förs vidare av underentreprenörens projektledare till lagbasen, och slutligen från lagbas till det ukrainska teamet. Ämnet behandlas på engelska och ukrainska (med inslag av ryska), samt med inskott av svenska. Vanko är tydligt en language broker i denna kedja, med mandat att föra vidare informationen till talare av olika språk och konkretisera och precisera det arbete som ska utföras.

\section{Arbetsplatsernas institutionella ordning och mångfalden språk}

I denna andra del av artikeln diskuterar vi hur de enskilda kedjorna synliggör och samverkar med en institutionell ordning för språkval på de två arbetsplatserna. Denna ordning tänker vi oss, liksom Roberts och Sarangi (1999), som delade normer, regler och rutiner om vad som kan tas för givet i en viss institutionell kontext, och som något som skapas och återskapas i (olika) enskilda samtal.

På båda arbetsplatserna fungerar språkvalet som ett sätt att strukturera arbetet $\mathrm{i}$ termer av deltagande. De olika språken förknippas med olika yrkesbefattningar och samverkar därmed med byggarbetsplatsernas hierarkiska ordning. Det är särskilt tydligt på den mindre arbetsplatsen, gropen, där arbetsledaren Berra är den (enda) svenska hantverkare som talar 
direkt till Wacek under pågående arbete. Som visats ger han framför allt uppmaningar om vad som behöver göras i nästa steg och befäster återkommande sin funktion som arbetsledare. Polskan, i sin tur, används mellan utförarna. Eftersom ingen annan på arbetsplatsen visar upp kunskaper i polska är det i praktiken ett språk för den grupp av arbetare som utför arbetsledarens instruktioner nere i gropen.

När det gäller de olika språkens roll i den institutionella ordningen på byggarbetsplatserna associeras svenska språket framför allt med arbetsledningen och de uppgifter som de utför: att hålla övergripande ansvar, utföra kontroller, planera nästa steg och diskutera lösningar på problem som uppstår. Vid husbygget kan dock också engelskan användas för motsvarande funktioner, som visats i exemplet med håltagning. Engelska är ett lingua franca på arbetsplatserna och ett språk som framför allt används mellan deltagare som befinner sig på olika nivåer i arbetsplatsernas hierarki. Vi ser det t.ex. i samtalen mellan Berra och Wacek, och mellan Peter och Vanko. Språkvalet är deltagarrelaterat, men i särskilt gropen får engelskan också en diskursrelaterad funktion i den interaktionella ordningen för språkval. I gropen kommer direktiven typiskt efter ett planeringsmoment på svenska och därför uppfattas byten till engelska i stort som en signal om att det nu kommer ett direktiv, riktat till Wacek, om att något ska utföras eller föras vidare.

Mångfalden språk, slutligen, har sin plats i den institutionella ordningen hos underentreprenörerna och utförarna. Deras arbetsspråk är ukrainska (med inslag av ryska) respektive polska. Flerspråkigheten på arbetsplatserna hanteras i det dagliga arbetet framför allt av arbetsledare och lagbasar. Som visats fyller särskilt lagbasen en viktig kommunikativ funktion i och med att han befinner sig i ett hierarkiskt mellanlager: Det är Vanko respektive Wacek som möjliggör kommunikation mellan hierarkins olika delar, genom att de talar både sitt teams språk och engelska. I relation till begreppet language broker kan särskilt Vanko lyftas fram, som visar sig vara utbildad jurist och säger att han talar många olika språk (men inga skandinaviska språk). Det är oklart om han arbetat inom byggbranschen tidigare; han konstaterar enbart att "times aren't good for lawyers in Ukraine" när en av oss forskare frågar hur det kommer sig att han är byggnadsarbetare i Sverige. Uppenbarligen är det språkkunskaperna som gör att han är lagbas. Men som exemplen visar innebär funktionen inte ett rent översättningsarbete; både Wacek och Vanko omformulerar, anpassar och konkretiserar direktiv samt organiserar utförarnas arbete i relation till direktivet. De fungerar därmed som länk både språkligt och professionellt. 
Sammantaget är den institutionella ordningen för språkval på de två arbetsplatserna sådan att alla inte förväntas tala med alla. Olika språk förknippas istället med en viss position på arbetsplatsen och har en förväntad plats i de kedjor som uppstår. Det är framför allt arbetsledare och lagbasar som hanterar mångspråkigheten i sitt dagliga arbete.

\section{Avslutande diskussion}

Den institutionella ordningen för språkval, där alltså alla inte förväntas tala med alla, skapas och återskapas interaktionellt på de två arbetsplatserna. Tydligast ser vi det i just kedjorna, där personer med olika befattningar talar med varandra om en och samma arbetsuppgift via lagbasen. Som visats utnyttjas kedjeformatet till och med under mer pressade situationer i gropen, då vatten läcker ut och en pump behöver hämtas (Ex. 3). Trots läckan frångår man varken den språkliga eller bygghierarkiska ordningen. Resultatet att "alla inte förväntas tala med alla" är en iakttagelse som har paralleller med Strömmers (2016) analys av städbranschen. Strömmer kopplar detta till outsourcing och utnyttjandet av underentreprenörer, och visar hur beställare undviker att tala direkt med utförarna om arbetet av rädsla för problem med särskilt kommande fakturor. Att det är flera lager av företagande kan vara en delförklaring också här till varför den institutionella ordningen ser ut som den gör, men inte den viktigaste förklaringen. Snarare är det så att en direkt kontakt mellan ledning och utförare skulle vara svår eftersom överlappande språkliga repertoarer saknas.

Så väl den institutionella ordningen som de enskilda interaktionerna behöver en language broker, alltså en person som fungerar som länk mellan arbetsledning och utförare. Intressant nog verkar detta vara mer eller mindre universellt för det flerspråkiga bygget: Såväl studier från Hong Kong (Handford \& Matous, 2015), Oslo (Kraft, 2017) som Qatar (Theodoropoulou, 2019) visar en hierarkisk miljö som är flerspråkig, men där alla inte nödvändigtvis talar varandras språk. I särskilt de två förstnämnda bekräftas lagbasarnas kommunikativa nyckelroll. Våra analyser visar tydligt att arbetet som lagbasarna gör är både kommunikativt - genom att de för vidare information - och en del av bygghierarkins logik genom att de organiserar och konkretiserar arbetet i nästa led. Att flerspråkigheten är begränsad till vissa positioner stratifierar arbetsplatsen på det sätt som Kraft (2017) visar i sin undersökning av en stor norsk byggarbetsplats. Kraft (ibid, s. 174) talar om situationen som en "naturalised logics of who can and cannot be where in the hierarchy of the workplace", och logiken vilar på linjeorganisationens ideal om effektivitet. Detta är särskilt tydligt vid 
husbygget, där gruppchefer är nödvändiga på grund av storleken. I denna logik får utförarna en ett begränsat handlingsutrymme utanför det egna arbetslaget och de saknar röst på byggarbetsplatserna, både i praktisk och symbolisk mening. Språkvalet i enskilda interaktioner avspeglar på så sätt hierarkin i vilka som inkluderas och ställs utanför, och den hierarkiska ordningen är också något som skapas och återskapas interaktionellt på byggarbetsplatserna. Noteras bör att inte heller vi har kunnat ge dessa arbetare röst i någon större utsträckning i vår forskning, trots att en forskarna (Weidner) behärskar polska. De pendlande arbetarna har långa arbetsdagar under den tid de är i Sverige och vill sällan ställa upp på intervjuer, vilket i sig speglar deras utsatta position på arbetsmarknaden.

Vi kan också konstatera att lagbasens kommunikativa uppgift ser något annorlunda ut mellan de två arbetsplatserna. Det kan framför allt förklaras med skillnader i spatialitet och temporalitet. I gropen är arbetet visuellt tillgängligt för alla deltagare och det typiska mönstret är att instruktioner och direktiv från arbetsledare till lagbas är korta och deiktiskt präglade. Lagbasen svarar sällan verbalt, utan förmedlar informationen vidare eller utför arbetet själv. På det stora bygget är arbetet utspritt över en stor yta och som i exemplet håltagning i parkett ska uppgifterna utföras i en serie, i flera lägenheter. Instruktionerna är mångordiga, med upprepningar och förtydliganden, och både arbetsledare och lagbas måste använda en mer utvecklad kod (jfr Bernstein, 1975), för att låna ett begrepp från skolvärlden.

I relation till tidigare studier av flerspråkigt arbetsliv är de studerade arbetsplatserna flerspråkiga i den bemärkelsen att olika språk används samtidigt, men i parallella samtal, av olika yrkesbefattningar. Det är alltså inte som på ett multinationellt företag, där engelskan idag ofta har nominell status som företagets officiella språk och därmed förväntas användas av alla anställda oavsett befattning. Det är inte heller utförarnas eventuella kunskaper i engelska eller svenska som ger dem tillträde till arbetsmarknaden i Sverige. Snarare är det viktigt för dem att kunna ett språk som redan talas av andra utförare på arbetsplatsen, så att de kan ingå i ett team. Det är på så vis den organisatoriska principen med enspråkiga grupper av utförare som är nyckel till arbete för den inresande arbetskraften. Språkfrågan är tydligt situerad i enskilda behov och ramar, snarare än reglerad top-down via en språkpolicy eller styrd av överordnade krav om kompetens i svenska. I tillägg till detta ser vi en påfallande funktionell uppdelning mellan (namngivna) språk, utan särskilt stor flexibilitet av det slag som ligger bakom begrepp som trunkerad språklig repertoar (Blommaert, 2010) eller transspråkande i den mening som Wei (2011) med flera för fram. Enstaka ord för verktyg och 
byggtermer på svenska inlemmas i de inresande arbetarnas professionella register, men det faller snarast inom kodväxling i dess traditionella mening i form av institutionella nyckelord. Metakommentarer till språkbruket är också mycket ovanligt, till skillnad från t.ex. undervisning på engelska i svensk högre utbildning (se t.ex. Söderlundh, 2010). Kanske beror det på arbetets manuella karaktär av att låta händernas arbete snarare än kommunikationen stå i fokus, på avsaknaden av övergripande språkpolicyer att förhålla sig till eller på att man mycket sällan samarbetar med personer utanför sitt team, vars språkliga repertoarer är okända och därmed kan behöva kommenteras metaspråkligt.

Avslutningsvis och sammanfattningsvis menar vi att artikelns viktigaste bidrag består av den fördjupade empiriska kunskapen om hur interaktionell och institutionell ordning samverkar på flerspråkiga byggarbetsplatser där det arbetar inresta hantverkare från olika länder. EU:s lagstiftning möjliggör arbete i annat land och statistik visar att arbetskraftspendlingen är särskilt stor inom byggbranschen. Att så är fallet beror uppenbarligen på att det finns ett stort behov av manuell arbetskraft. Därtill tycks byggbranschens hierarkiska organisation kunna hantera en mångfald språk på ett sätt som fungerar väl för branschen: Varje plats i hierarkin är som visats associerad med ett visst språk och de kedjor som bildas tillåter språkbyten mellan stegen i kedjan. Lagbasen har mandat att inte enbart eftersträva översättningar, utan organiserar, konkretiserar eller utför själv arbetet. Han är en language broker, men också en del av bygghierarkins logik.

\section{Referenser}

Angouri, J. (2014). Multilingualism in the Workplace: Language Practices in Multilingual Contexts. Multilingua 33(1-2), 1-9. doi:10.1515/multi-2014-0001

Arbetsmiljöverket (2019). Fortsatt ökning av utländsk arbetskraft, främst från Polen. Hämtad från https://www.av.se/press/fortsatt-okning-av-utlandsk-arbetskraft-framst-fran-polen. 201904-08

Auer, P. (1984). Bilingual Conversation. Amsterdam: Benjamins.

Berger, P.L. \& Luckmann, T. (1991). The social construction of reality: a treatise in the sociology of knowledge. (Repr.) London: Penguin.

Bernstein, B. (1975). Class, codes and control: theoretical studies towards a sociology of language. New York: Schocken Books. 
Blommaert, J. (2010). The Sociolinguistics of Globalization. Cambridge: Cambridge University Press.

Coupland, N. (2003). Introduction: Sociolinguistics and Globalisation. Journal of Sociolinguistics, 7(4), 465-472. doi:10.1111/j.1467-9841.2003.00237

Franziskus, A., \& Gilles, P. (2012). 'Et le präis direct etikett'. Non-overlapping repertoires in workplace communication in Luxembourg. Sociolinguistica 26 (1), 58-71.

doi.org/10.1515/soci.2012.26.1.58

García, O., \& Wei, L. (2015). Translanguaging, Bilingualism, and Bilingual Education. I W.E., Wright, S., Boun, \& O. García (Red.), The Handbook of Bilingual and Multilingual Education, Malden, MA: Wiley-Blackwell, 223-240.

Gluch, P., \& Räisänen, C. (2009). Interactional Perspective on Environmental

Communication in Construction Projects. Building Research \& Information, 37(2), 164-175. doi:10.1080/09613210802632849

Goffman, E. (1974). Frame analysis: An essay on the organization of experience. Harvard University Press.

Goffman, E. (1981). Forms of talk. (University of Pennsylvania publications in conduct and communication.) Philadelphia: University of Pennsylvania P.

Goldstein, T. (1997). Two languages at work: bilingual life on the production floor. Berlin; New York: Mouton de Gruyter.

Gunnarsson, B.L. (2014). Multilingualism in European Workplaces. Multilingua, 33(1-2), 11-33. doi:10.1515/multi-2014-0002

Handford, M., \& Matous, P. (2011). Lexicogrammar in the International Construction Industry: A Corpus-based Case study of Japanese-Hong-Kongese On-site Interactions in English. English for Specific Purposes, 30(2), 87-100. doi:10.1016/j.esp.2010.12.002

Handford, M., \& Matous, P. (2015). Problem-solving Discourse on an International Construction Site: Patterns and practices. English for Specific Purposes, 38, 85-98. doi:10.1016/j.esp.2014.12.002

Hazel, S., \& Svennevig, J. (2018). Multilingual workplaces: Interactional Dynamics of the Contemporary International workforce. Journal of Pragmatics, 126, 1-9. doi:10.1016/j.pragma.2017.11.005

Hovens, D. (2019). 'Screwed'. The Discursive Construction of Vocational Ethics in a BlueCollar Workplace Characterised by Transience and Multilingualism. Föredrag vid Workshop on Work Migration and Multilingualism 28-29/8-2019. Södertörns högskola, Stockholm. 
Jansson, G. (2013). Äldreboendet som flerspråkig arbetsplats. Policy och praktik. I B. Bihl, P. Andersson \& L. Lötmarker (Red.), Svenskans beskrivning, 32, 118-129.

Kahlin, L., Tykesson I., \& Romanitan M. (2019). Reparationssekvenser i nyanlända läkares samtal med kolleger och patienter. Språk och interaktion, 5(2), 27-44.

Kraft, K. (2017). Constructing Migrant Workers: Multilingualism and Communication in the Transnational Construction Site. Unpublished PhD dissertation. University of Oslo.

Kraft, K. (2020). Transience and Tunnel Esperanto: A study of multilingualism, work and relationship-building on a tunnel mining project, International Journal of the Sociology of Language, 2020(264), 163-186. doi: https://doi.org/10.1515/ijsl-2020-2098

Lilja, N., \& Tapaninen T. (2019). Suomen kielen käyttämisen ja oppimisen mahdollisuudet ammatillisen oppilaitoksen rakennusalan vuorovaikutustilanteissa. (Using and learning Finnish as a second language in construction site interaction). Puhe ja kieli, 39(1), 69-98. doi: $10.23997 /$ pk.74506

Lønsmann, D. (2015). Language Ideologies in a Danish Company with English as a Corporate Language: 'It has to be English'. Journal of Multilingual and Multicultural Development, 36(4), 339-356. doi:10.1080/01434632.2014.921187

Lønsmann, D., \& Kraft, K. (2018). Language Policy and Practice in Multilingual Production Workplaces. Multilingua, 37(4), 403-427. doi:10.1515/multi-2017-0088

Mondada L. (2004). Ways of "Doing Being Plurilingual" in international work meetings. In R. Gardner \& J. Wagner (eds) Second Language Conversations (pp. 1839). London, Continuum. doi:10.5040/9781474212335.0005

Mondada, L. (2007). Bilingualism and the Analysis of Talk at Work: Codeswitching as a Resource for the Organization of Action and Interaction. I M. Heller (Red.), Bilingualism: A Social Approach. Basingstoke: Palgrave Macmillan. doi:10.1057/9780230596047_14

Mondada, L. (2019). Conventions for Multimodal Transcription. https://www.lorenzamondada.net/multimodal-transcription

Nelson, M. (2014). 'You need help as usual, do you?': Joking and swearing for collegiality in a Swedish workplace. Multilingua, 33(1-2), 173-200. doi:10.1515/multi-2014-0008

Nikolaidou, Z. (2014). Dominant Workplace Literacies in Vernacular Disguise: Disputable Discourses on the Production Floor. I A-C. Edlund, L-E. Edlund \& S. Haugen (Red.), Vernacular literacies: Past, present and future. Umeå: Umeå university \& Royal Skyttean Society, 45-57. 
Piller, I., \& Lising. L. (2014). Language, employment, and settlement: Temporary meat workers in Australia. Multilingua, 33(1-2), 35-59. doi:10.1515/multi-2014-0003

Rampton, B. (1998). Language Crossing and the Redefinition of Reality. I P. Auer (Red.), Code-switching in Conversation: Language, Interaction and Identity, 290-317.

Räisänen, T. (2013). Professional Communicative Repertoires and Trajectories of Socialization into Global Working Life. Jyväskylä: Jyväskylä studies in humanities (216).

Sarangi, S., \& Roberts, C. (1999). The dynamics of interactional and institutional orders in work-related settings. I Talk, work and institutional order: Discourse in medical, mediation and management settings, I C. Roberts \& S. Sarangi (Red.), Talk, Work and Institutional Order: Discourse in Medical, Mediation and Management Settings, 1-61. Berlin: Walter de Gruyter.

Sidnell, J. (2010). Conversation Analysis: An introduction. Malden, MA: Wiley-Blackwell.

Stivers, A. (2004). "No no no" and Other Types of Multiple Sayings in Social Interaction. Human Communication Research, 30(2), 260-293. doi:10.1111/j.1468-2958.2004.tb00733.x

Strömmer, M. (2016). Affordances and constraints: Second language learning in cleaning work. Multilingua: Journal of Cross-Cultural and Interlanguage Communication, 35 (6), 697-721. doi:10.1515/multi-2014-0113

Svennevig, J. (2018). "What's it Called in Norwegian?" Acquiring L2 Vocabulary Items in the Workplace. Journal of Pragmatics, 126, 68-77. doi:10.1016/j.pragma.2017.10.017

Söderlundh, H. (2010). Internationella universitet - lokala språkval: Om bruket av talad svenska i engelskspråkiga kursmiljöer. Diss. Uppsala: Uppsala universitet, 2010. Uppsala.

Theodoropoulou, I. (2019). Blue-collar Workplace Communicative Practices: A Case Study in Construction Sites in Qatar. doi.org/10.1007/s10993-019-09518-Z

Wei, L. (2011). Moment Analysis and translanguaging space: Discursive construction of identities by multilingual Chinese youth in Britain. Journal of Pragmatics, 43(5), 1222-1235. doi:10.1016/j.pragma.2010.07.035

\footnotetext{
i Söderlundh och Kahlin har författat artikeln och ansvarar för texten. Materialinsamling, transkription och analys har skett i samarbete mellan alla tre författare.
} 
ii Vi vill rikta ett stort tack till projektkollegan Leelo Keevallik som genomfört materialinsamlingen med oss.

iii Transkriptionerna utgår från Mondada (2019). Endast de mest betydelsefulla synliga resurserna har noterats.

iv Vi vill rikta ett stort tack till fil.dr Natalia Ringblom för hjälp med översättning och transkribering av samtal på ukrainska och ryska. 